\title{
ロングパルスエキシマレーザーの組織蒸散能および ファイバー導光に関する研究
}

Fiberoptic Delivery and Vaporization Using a Long Pulse Excimer Laser

\author{
荻野均, 風林均, 岡本 好史, 伴敏彦 \\ 京都大学医学部心臟血管外科 \\ 干606 京都附京都市左京区聖護院川原朾54
}

Hitoshi OGINO, Hitoshi OKABAYASHI, Toshihumi OKAMO'TO and Toshihiko BAN

Kyoto University, Faculty of Medicine, Dept. of Cardiovasc. Surgery

要 旨

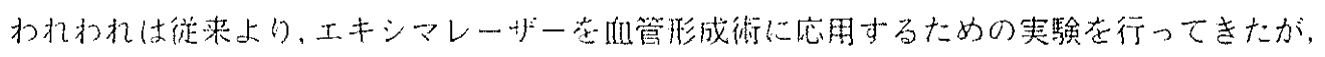
使用してきた日本電池社棐エキシマレーザー装置EXL200のパルス幅が20nsとショートパルス タイプであったため，ファイバー入射面が破損しやすく十分なファイバー出射端出力が得ら扛 ていなかった。この問題の解決のために、レーザ一装置に改良を加えパルス幅を20nsから70

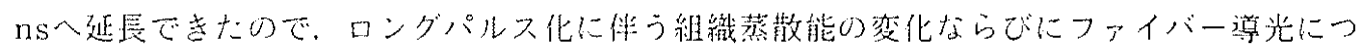
いて基磁的罢駼定行った。

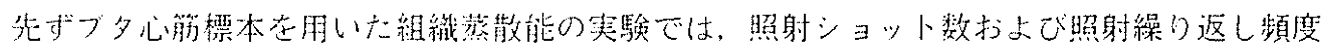
の曙㭁に伴い．500ショットならびに60ppsまで蒸散された組織の深さの増加がるられたが、 以後はプラトーに達する㑯问にあった。また。变色域の広がりは，照射ショット数执よざ繰り

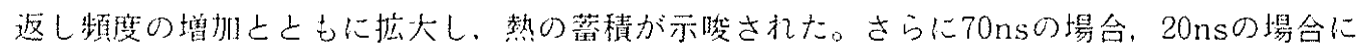

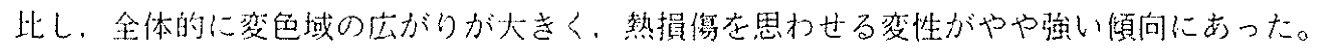

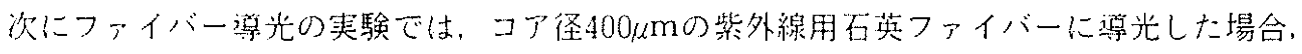
20nsでは出射端で4mJ/pulse (32 $\mathrm{mJ} / \mathrm{mm})$ の出力ですったのに比べ，70nsでは16mJ/pulse $(128 \mathrm{~mJ} / \mathrm{mm})$ の高出力が交定して得的だ。またフタ大動脈壁を用いたファイバー照射によ る組織蒸散能の比較では，70nsの場合熱損傷を思わせる变性がやや弶いものの，20nsの湯合 に比べ蒸散能の有意な低下を認めなかった。従って，20nsから70nsへのパルス愊延長に伴い 熱損傷がやや強くなる僋向にあったが，組織蒸散能に有意な差を諗めず，逆にファイバーへの

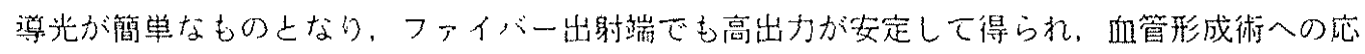
用が容易なものとなった。

\section{Abstract}

We studied the ablative effect of a long-pulse excimer laser (XeC1, 308nm, pulse- 
width;70ns, pulse-energy; $42 \mathrm{~mJ} /$ pulse) on porcine myocardium, and compared that with that of a short-pulse one $(308 \mathrm{~nm}, 20 \mathrm{~ns}, 42 \mathrm{~mJ} /$ pulse) which we had used before. In the second experiment, after coupling this long-pulse excimer laser light into a quartz fiber $(400 \mu \mathrm{m}$ core-diamter $)$, we measured the distal fiber-end laser energy and examined the ablative effect of the laser transmitted through the fiber.

In result, the cuts produced with the long-pulse laser clearly defined such sharp edges as with the short-pulse one. With the both long-and short-pulse laser, the depth of cuts increased with the number of pulses and the pulse repetition rate. The width of discoloration around the cut margin also increased with the number of pulses and the pulse repetition rate. However, as a whole, the width with the long-pulse was broad er than that with the short-pulse, which showed the thermal injury with the long-pulse was a little more than with the short-pulse. In the second experiment about the fiber transmission, the distal fiber-end power of $16 \mathrm{~mJ} / \mathrm{pulse}(128 \mathrm{~mJ} / \mathrm{mun})$ with the long-pulse was obtained successfully, compared with $4 \mathrm{~mJ}$ /pulse with the short-pulse. Besides, the ablative effects of the laser transmitted via the fiber were little different between the long-and short-pulse, though the thermal injury was somewhat more with the long-pulse.

The result suggested the ablative effect of the long-pulse excimer laser were little different with the shoht-pulse, except a slight increase of thermal injury with the long-pulse, and that the elongation of pulse width could make it easy to couple the laser light into the fiber. Therefore, it was expected we would be able to employ this long-pulse excimer laser device to clinical laser angioplasty in no distant future.

key words : excimer laser, long-pulse, ablative effect, thermal injury, fiber transm ission

\section{1. 目的}

我々は従来より，熱損傷が少なく鋭利な組織蒸散が可 能とさ机ているエキシマレーザー1"一-1)点血管琲成術。

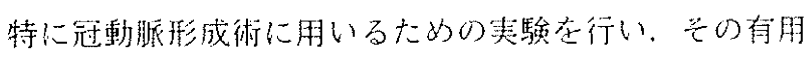
性定報告してきだいけ。しかし未だエキシマレーザー 光のファイバー獐光に問題を有し, 十分なファイバー出 射端出力が得ら机ていない現状でする。の解決法の一 つとして、エキシマレーザーのパルス輻在延長し、ファ イバー入射端でのピークパワーを㧕え，ファイバーの破

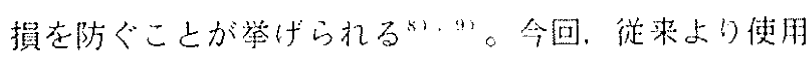
してきたエキシマレーザー装置EXL-200（日本電池社 製)に改良を加え，パルス幅を徉来の20nsから70nsま で延長した装置を入手できた。文献的には，Singleto $\mathrm{n}^{93}$ やTaylor'1" らがエキシマレーザーのパルス楅延長 に伴う蒸散能の变化ならびにファイバー尊光に関する報 告在しているが，今回われわれが使用したものとは異な るレーザー装置，異なるパルス輻での比較であり，また 彼らの蒸散能に関する報告は蒸散しきい值中心のもので,
熟損鹪在含妨た詳細なものが不明である。さらに、わが 国ではパルス增70nsのロングパルスエキシマレーザー 装置は他に開発さ机て执らず。したがってこのパルス幅

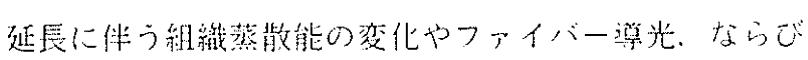
に従来の20nsのものとの比較検討は四味京るこ上之考 えられ、基砧的実験老行ったので報告する。

\section{2. 対象および方法}

1) ロングパルスエキシマレーザーの組織蒸散能

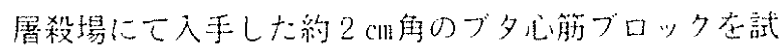
料とし、ロングパルスエキシマレーザ一装置として日本 電池社整改良型 $\mathrm{EXL}-200(\mathrm{XeCl}, 308 \mathrm{~nm}$ ，パル又幅； $70 \mathrm{~ns}$ パルスエネルギー；42 mJ/pulse)在用いた（図 1)。先ず、語電体多層膜ミラーにて水平方向のレーザー 光を垂直方向に偏向し，焦点距離200 $\mathrm{mm}$ の合成石英レン ズによりブ夕心筋に集光照射した（図 2)。照射した標 本は10\%ホルアリン液で固定し、24時間後に蒸散部に平 行に糹切を加えた。その割面より，蒸散された深さおよ 
び蒸散部周囲の変色域幅を計測し, 繰り返し頻度20pps で照射ショット数を100〜1,000ショットまで100ショッ トずつ増加させた場合ならびに連続ショット数500 ショットで照射繰り返し頻度を10〜70ppsまで10ppsず つ増加させた場台上の関係について検討した。また，蒸 散部扩よびその周国の変化についてへマトキシリンーエ オジン染色標本により組織学的に検討した。更に，以上 の結果を従来のショートパルスエキシマレーザー装置の

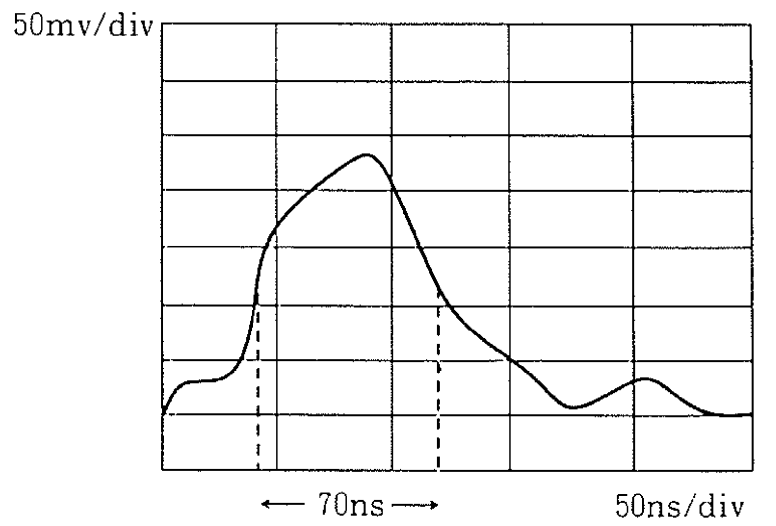

図 1 ロングパルスエキシマレーザー波形 パルス幅 70ns
揚合（パルス幅；20ns,パルスエネルギー；42mJ/pulse） と比較した。

2) ロングパルスエキシマレーザー光のファイバーへ の導光実験

$11 \times 18 \mathrm{~mm}$ の矩形レーザー光を焦点距離501mm の合成面英 レンズで集光し，コア径 $400 \mu \mathrm{m}$, 長さ $3 \mathrm{~m}$ の三菱電線工

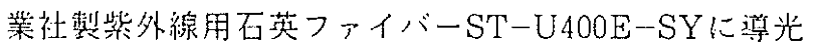
し、ファイバー出射端での出力をGentec社製ジュール メーターED-200にて测定した（図 3)。また出射端出 力の实定性芯みるため，連続20,000抄よび40,000ショッ

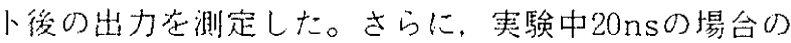
最高出力であった $3.5 \mathrm{~mJ} / \mathrm{pulse}$ に両者のフアイバ一出 射端出力を調節固定し，ブタ大動脈壁に0. $5 \mathrm{~mm}$ の距離か らエキシマレーザーのファイバー照射を行い，20ns上 $70 \mathrm{~ns}$ での蒸散能を光顕レベルで比較した。

\section{3. 結 果}

実験中，雨レーザー装䈯ともパルスエネルギー $42 \mathrm{~m}$

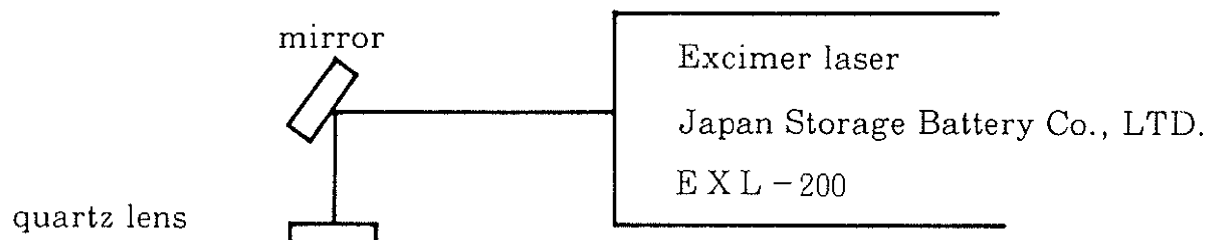

laboratory jack

図 2 エキシマレーザーの照射システム

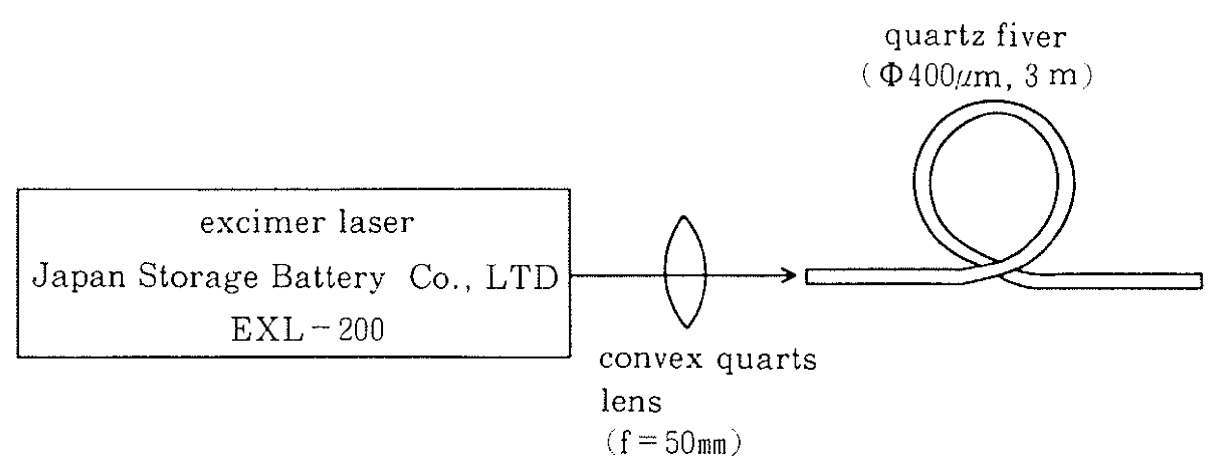

Gentec lnc. Joule meter $\mathrm{ED}-200$

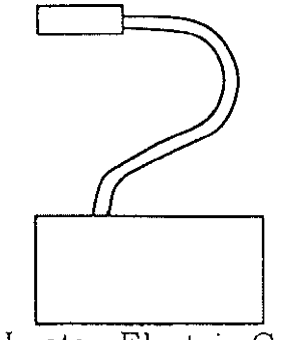

Iwatsu Electric Co. synchroscope SS - 5421

図 3 エキシマレーザー光のファイバー導光システム 


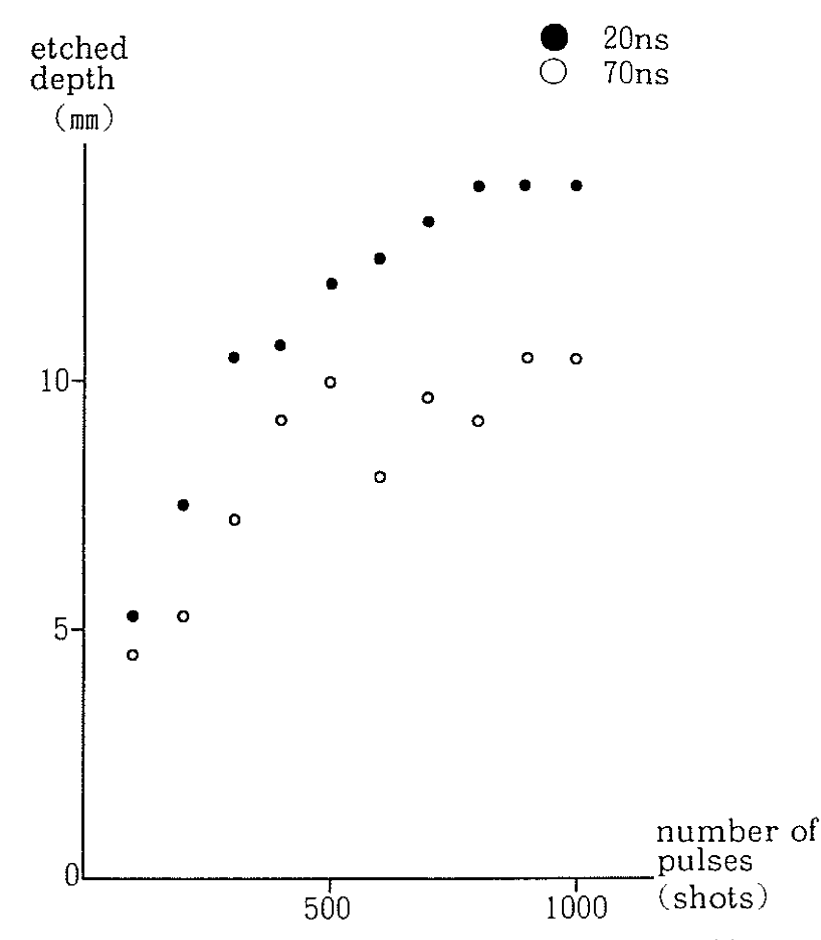

照射ショット数と蒸散された組織の深さ（照射繰 り返し頻度；20pps)

width of

discoloration

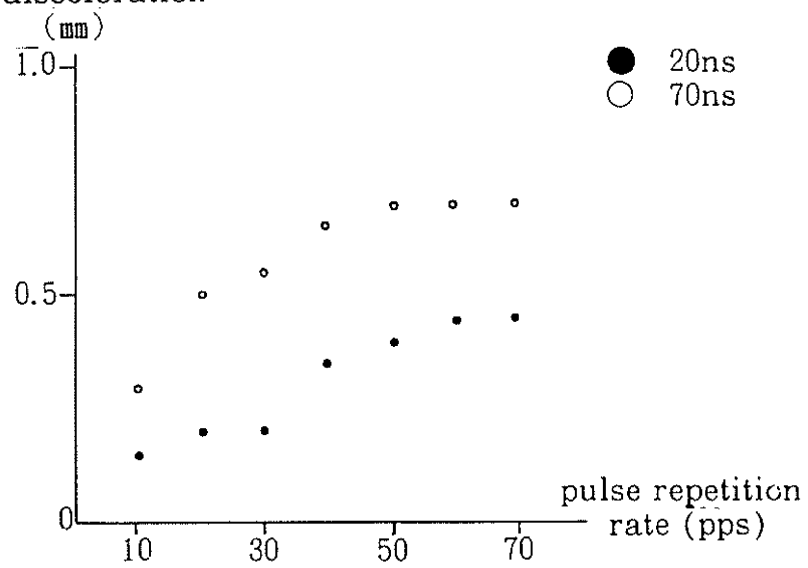

照射ショット数と変色域の広がり（照射繰り返し

頻度 ; 20pps)

J/pulse)やブ夕心筋表面のスポットサイズ(0.6minh)は 同一で，従って心筋表面でのエネルギー密度は阔者上も 同一の70mJ/mưであった。

1) - A ; 照射ショット数と蒸散された組織の深さ

$70 \mathrm{~ns}$ の場合は500ショットまで、20nsの場合は800 ショットまで. 共に照射ショット数の增扣に比例して深 さの增加がみられたが，以後はプラトーに達する傾向に あった（図 4，左）。

1)－B；照射繰り返し頻度と蒸散された組織の哚さ 雨者亡も，繰り返し頻度の增加に伴い深さの堌加がみ られた（図 4，右）。

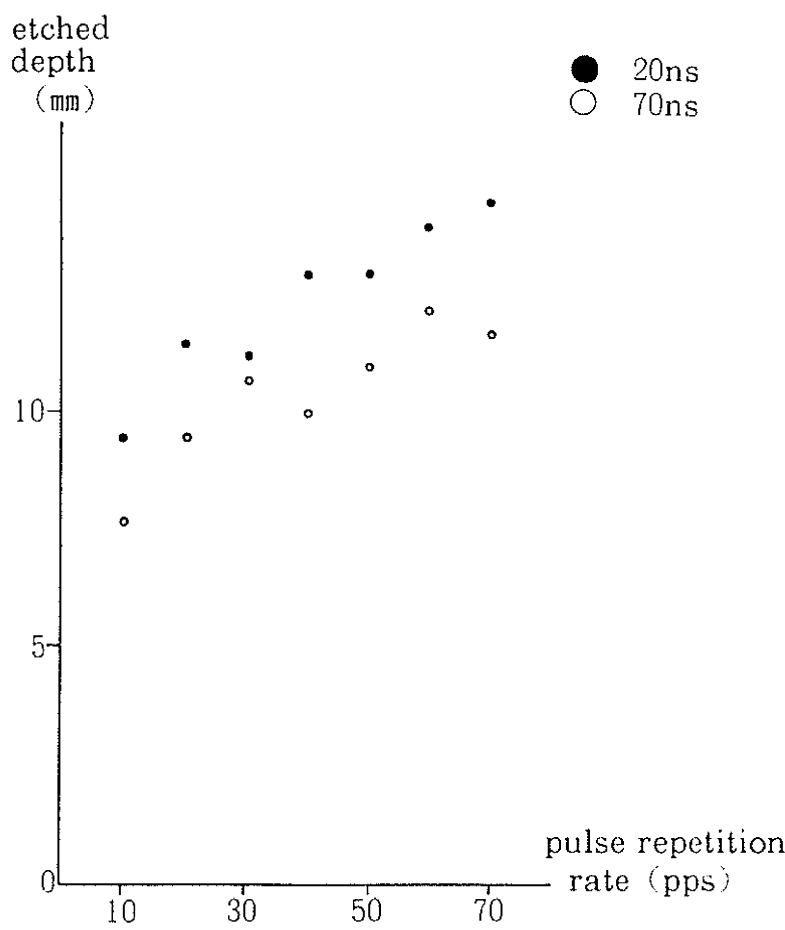

照射繰り返し頻度と变色域の広がり（照射ショッ 卜数 ; 500shots)

図 4

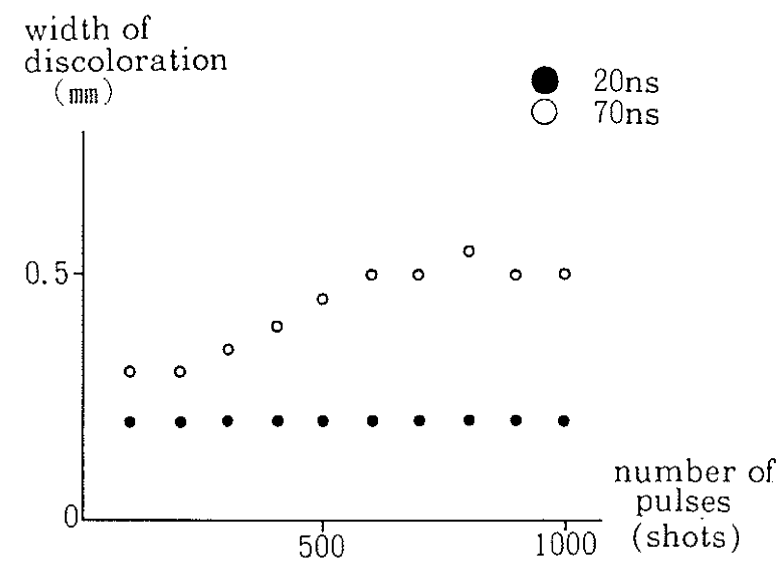

照射繰り返し頻度し蒸散された組織の深さ（照射 ショット数 ; 500shots)

図 5

1) $-\mathrm{C}$; 照射ショット数之変色域の広がり

$70 \mathrm{~ns}$ では，20nsの場合に比べ，全体的に变色域が広 く、600ショットまでは増加傾向にあった（図 5, 左）。

1) - D ; 照射繰り返し頻度と变色域の広がり

同様に, 70nsでは20nsより変色域の広がりが大きく。 ともに50ないしは60ppsまで広がりの增加がみら㧈，以 後はプラトーに達した（図5，右）。図6は，20nsと70 nsの間で実際のブ夕心筋標本割面を比較したものであ るが.70nsの標本で辺縁鋭利な蒸散部周辺に熱損偪を 思わせる变色域が㬏広くみら独た。吉たへマトキシリ ンーエオジン染色による光顕標本でも，蒸散部はよもに 
1) $20 \mathrm{~ns}$

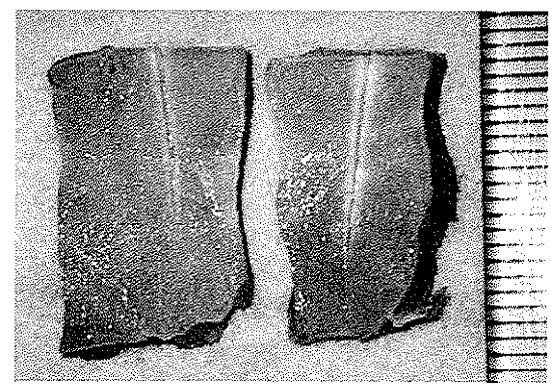

L : 30pps, 500shots

$R: 40$ pps, 500shots

2) $70 \mathrm{~ns}$

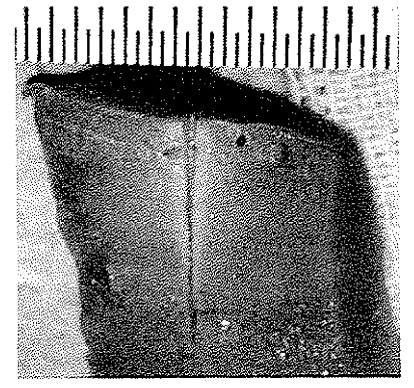

30 pps 500 shots

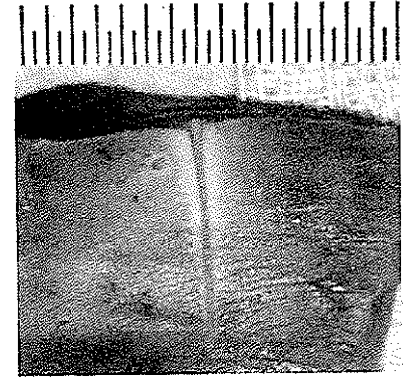

$40 \mathrm{pps}$

500 shots
図 6 エキシマレーザー照射後のブタ心筋割面; 肉眼所 見

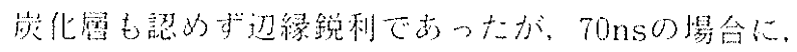

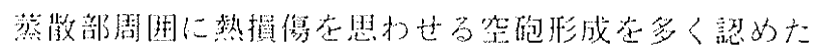
(図 7)。

\section{2)：ファイバー章光}

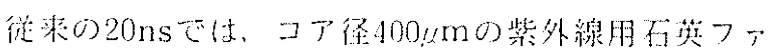

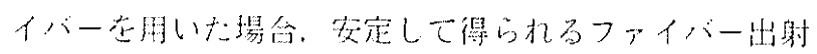
端出力は $4 \mathrm{~mJ} / \mathrm{pulse}$ (エネルギー渻度；32 $\mathrm{mJ} / \mathrm{m}$ ) で かった。しかし、今回の70nSへのパルス幅延長に伴い， レーザー装琶本体のパルスエネルギーが $60 \mathrm{~mJ} / \mathrm{pulse}$ ) 条件下で、ファイバー出射端で $16 \mathrm{~mJ} /$ pulse $128 \mathrm{~mJ}$ !

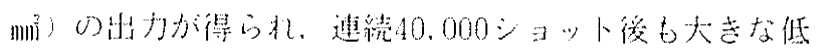

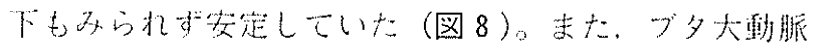

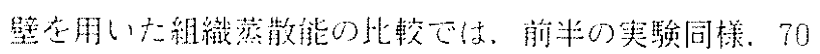

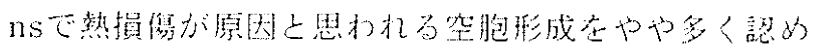

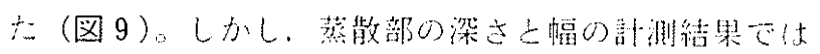

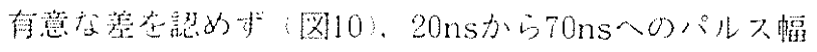

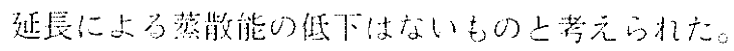

\section{4. 考案}

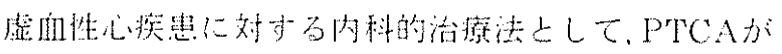

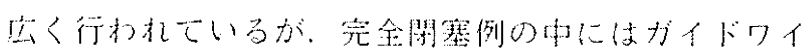

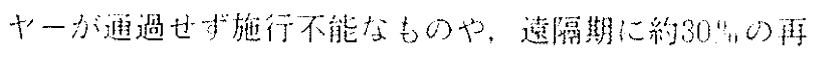
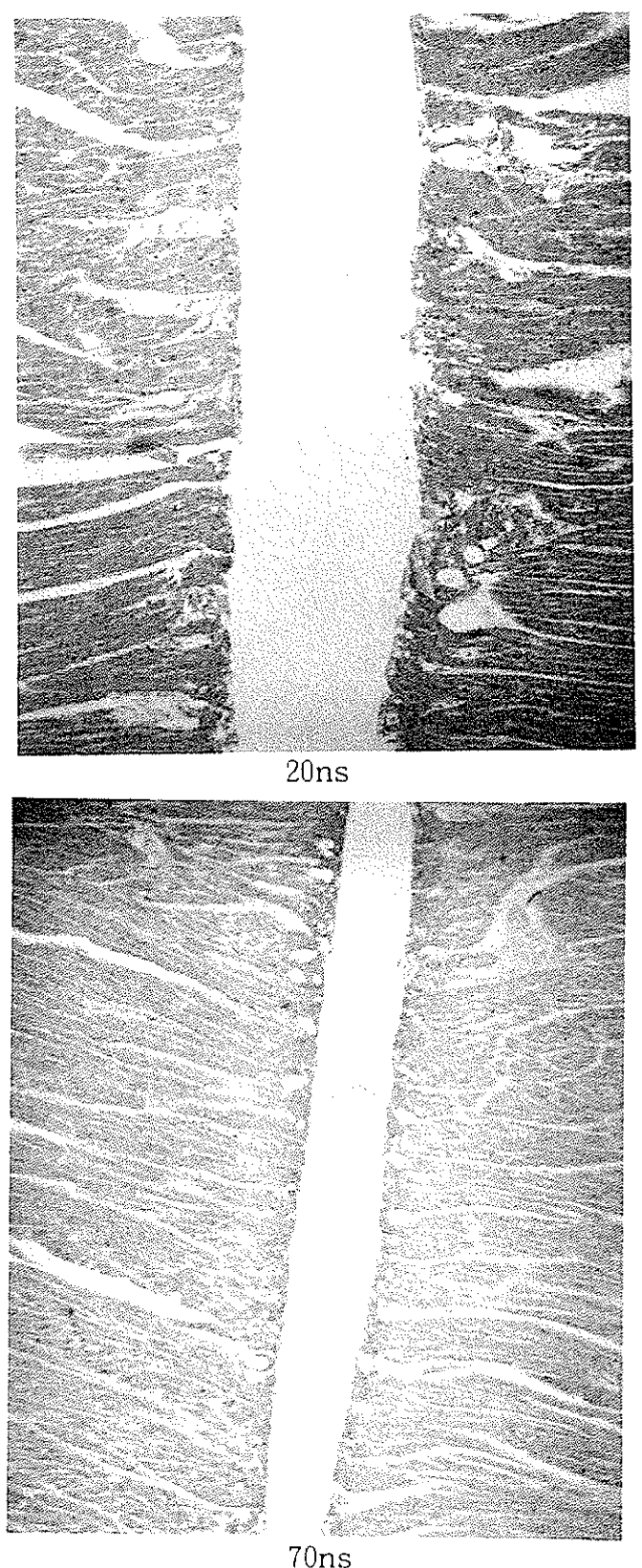

図 7 エキシマレーザー照射後のブタ心筋標本; 光顕所 見 (30pps, 500shots, H-E染色)

狭窟が発生するなよ゙，来な゙满是できる結果が得られてい ない。执われはこれらの䦖題在解決打る乎法上して， レーザーによりプラーク在蒸散し内腔在確保する るlaser

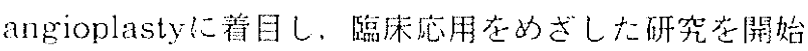
した。用いるレー+゙ーとして、既存のAr, Nd-YAG等 のthermal laserと睤なり，紫外のパルスレーザーであ るため熱損㑺が少なく鋭利な組織の蒸散が可能とされて いるエキシマレーザーい・复伹管形成術，特に維小動

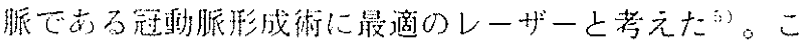
のエキシマレーザ一在周い, transluminal laser angioplasty ${ }^{i ;}$ やopen laser endarterectomy 行ったが，我々が月いたエキシマレーザー装琶执よびそ のdelivery systemでは，ファイバー出射端での出力が 


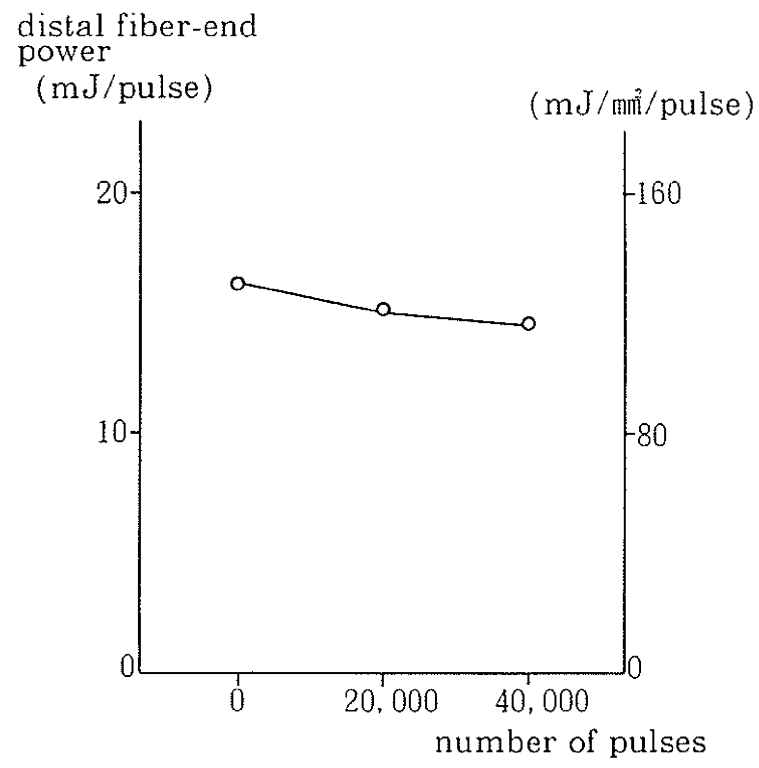

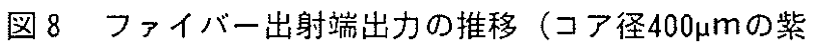
外線用石英ファイバー，レーザー本体パルスエネ ルギー；60 mJ/pulse，照射繰り返し頻度; $30 \mathrm{pps）}$

十分なものではなく満足できる実験結果が得られなかっ た。すなわち，用いたエキシマレーザー装置はパルス稫 が20nsのショートパルスタイプで, ファイバー入射端 でのピークパワーが高くなるため石英ファイバーの入射 端が破損しや寸く，安定して得られる出射端出力はコア 径 $400 \mu \mathrm{m}$ の石英ファイバーで $4 \mathrm{~mJ} / \mathrm{pulse}$ (エネルギー 密度； $\left.32 \mathrm{~mJ} / \mathrm{mm}^{2}\right)$ 程度であった。并こで、より高いファ イバー出射端出力を得るための対策上して，エキシマ レーザー装犆のパルス幅を延長し、ファイバー人射端で のピークパワーを在抑え，ファイバーの破損を防ぐことが

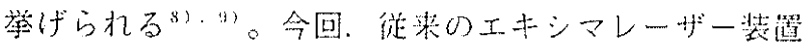
に改良を加え，パルス幅を20nsから70nsまで延長した 装置を入手できた文献的には, Singleton" ${ }^{3}$,Taylor " らがエキシマレーザーのロングパルス化に伴う蘢散能の 变化ならびにファイバ一臫光に関す石報告をしているが。 わ机机が使用したものと異なるレーザー琵置。琵なる パルス幅での比較であり，また蒸散能に関して，彼らの 報告は蒸散しきい值中心のものであり，熱損侮范台めた 詳細なものが不明である。さらに。加国ではパルス幅

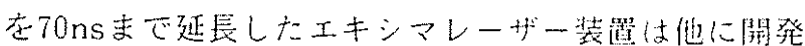
されて㧍らず，したがって、この70nsへのパルス幅延 長に伴う組織蒸散能の变化やフォイバー尊光。ならびに

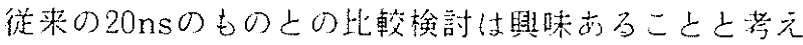
られ，以下の基礎的実験を行った。

先ず、ロングパルス化に伴う組織蒸散能の变化に関す る夷験では，ブタの心筋を試料として明い，20nsと70 nsの闻者とも同パルスエネルギー（42 mJ/pulse)下に

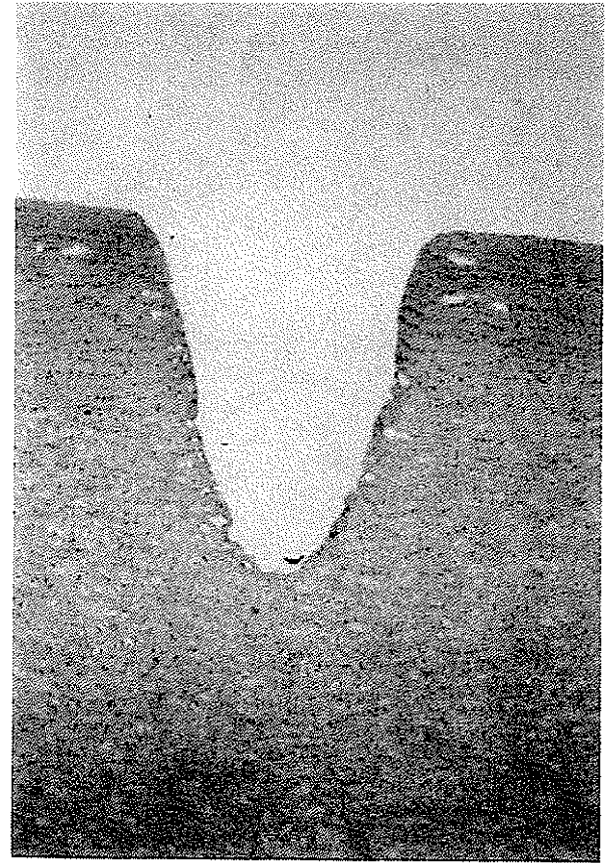

PW 20 ns

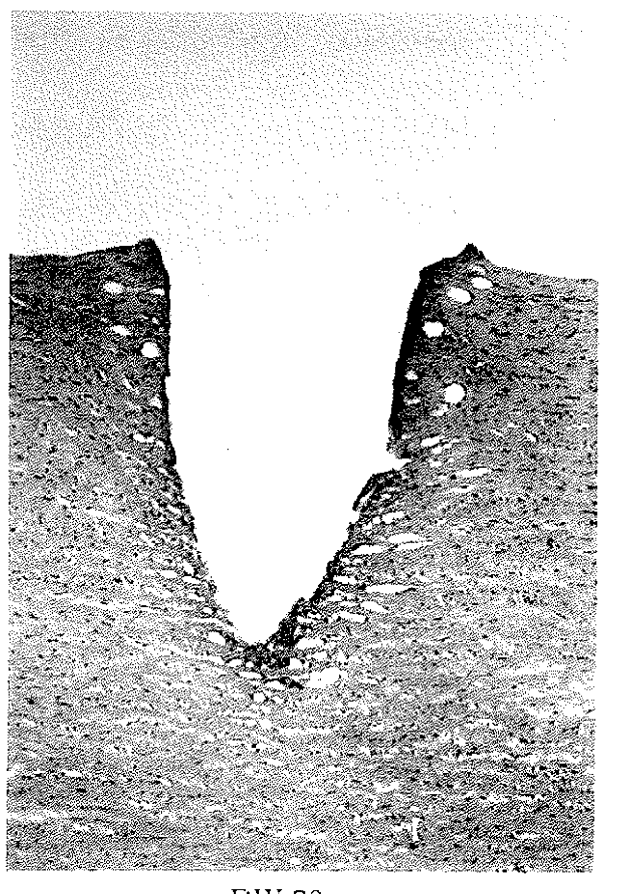

PW 70 ns

図 9 エキシマレーザーファイバー照射後のブタ大動脈 壁摽本（30pps，500shots，0.5mm非接触照射，H-E 染色)

行った。照射ショット数と蒸散部の深さの関係では， ショット数の増加に伴い深さの増加がみられたが， 500 ショット以降はプラトーに達する傾问にあった。こ挑は レーザー光の焦点をブ夕心筋表面に合わせているため， 表面近くではショット数に伴い深さの増加がみられたが. 哚くな扎げそれだけ焦点から離れ，エネルギー密度が減 少し蒸散能が低下したと考えら机た。次に照射繰り返し 頻度亡蒸散部の深さの関係では，繰り返し頻度の增加に 


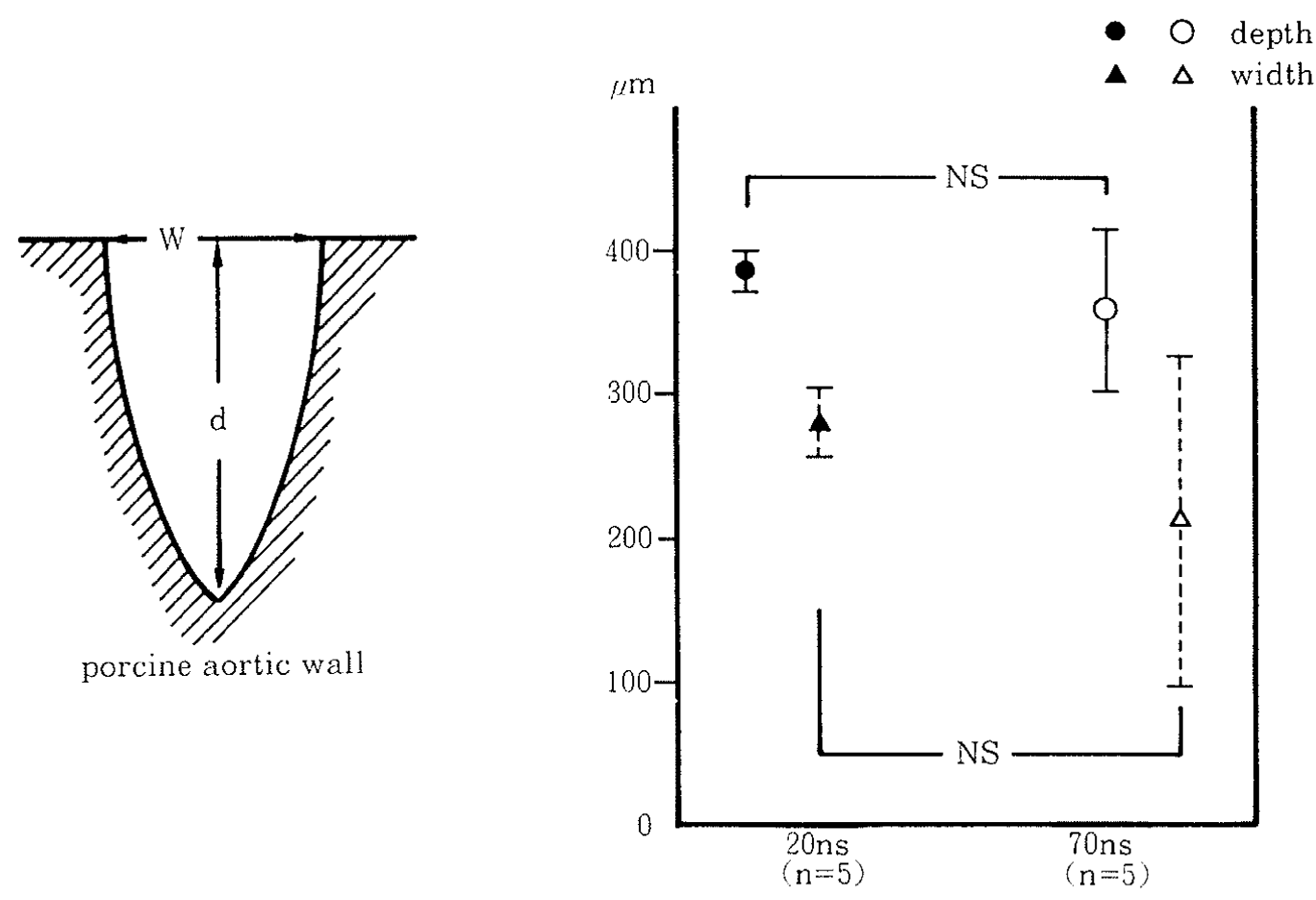

図10 エキシマレーザーファイバー接触照射後の組織蒸散能

(30pps, 500shots, $0.5 \mathrm{~mm}$ 非接触照射)

伴い深さの増加がみられた。この2項目の実娩で，70 nsの場合, 20nsの場合に比べ全体的に蒸散さ㧈た深さ がやや少ない傾向にあった。これは，Singleton"や Taylor (1)らもパルス幅が蒸散しきい値にあたえる影響 は少ないよしているように，パス稫の違いよいうより， 2つの異なるエキシマレーザー装置から発生するビーム 品質の差や，プロトタイプであるが故の高繰り返し頻度 下での出力低下などが要因とも考えられた。照射ショッ 卜数之变色域ならびに繰り返し頻度と变色域の関係では. ともに70nsで，20nsより変色域の広がりが大きく，等 損伤之思われる変性がやや強い傾向にあった。へマトキ シリンーエオジン染色による光顕標本でも，70nsのも のに変色域に相当して熱損賃に上ると思われる空胞形成 を多く認めだ。これは，ビーム広がり角やエネルギーの 一様性などビームの品筫の違いが原因とも考えら㧈るが, Wollenek'1り ら ArFのエキシマレーザーを用いた実

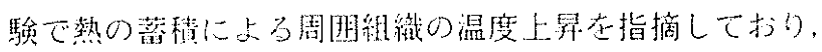

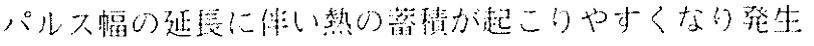

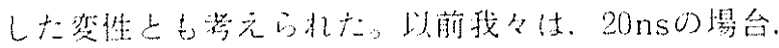

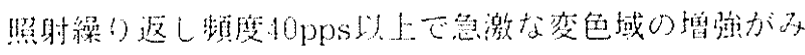

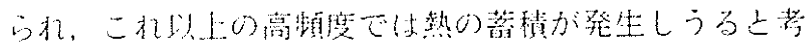

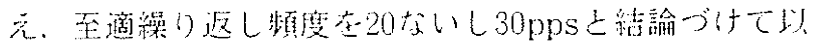

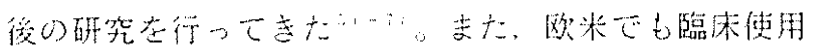

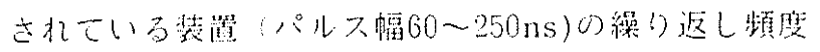

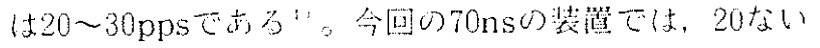

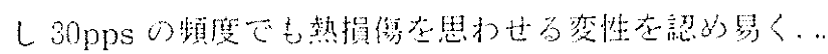

パルス幅の延舆に伴う熱揁䇰の堌加上して，至適繰り返

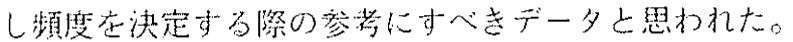

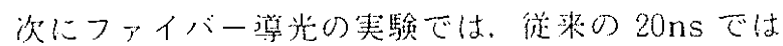

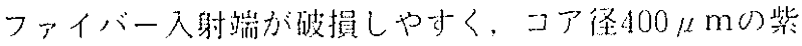
外鼣胢石英ファイバーで灾定して得ら扟万出射端出力は $4 \mathrm{~mJ} /$ pulse $\left(32 \mathrm{~mJ} / \mathrm{mm}^{2}\right)$ であった。しかし、今回の70 nsでは, $16 \mathrm{~mJ} /$ pulse $(128 \mathrm{~mJ} / \mathrm{mm}$ )か連続40, 000 ショ 卜後もあまり低下せ执安定して得的机た。 Litvack! らに上㧈ば, 血管組織の蒸政しきい値は。 $308 \mathrm{~nm}, \mathrm{XeC}$

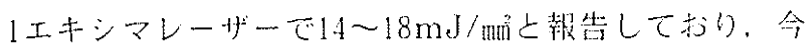

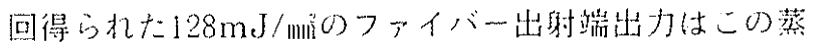
散しきい値在はるかに越えるものであった。

また、出射端出力在 $3.5 \mathrm{~mJ} / \mathrm{pulse}$ 同一に設定し繰 り返し頻度30ppsで行ったファイバー照射比較実験では，

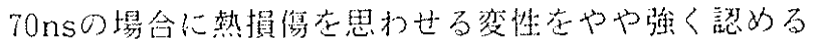
傾问にむったが、蒸散部の深さに差はみられず, Single-

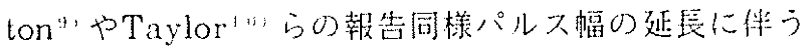
蒸散能の低下はみられなかった。

街って，今回のロングパルスエキシマレーザ一装㖥を 用いた埸欱、従来のショートパルスの場台に比ベやや熱 損第の增強がみら扎るものの，パルス幅の延長に伴う蒸 散能の低下も两ら㧈ず。はるかに高いファイバー出射端 出力が安定して得ら机るようになり，監床での血管形成 術への応用が容易なものとなると考无ら㣗た。ただ。よ り高いファイバー出射端出力老定して得るためや、マ ルチファイバーへの等光のためには, 今捘さらにパルス 
マレーザー用いたLaser Endarterectomy, 日本

5. 結 論

1.エキシマレーザー装置のロングパルス化に伴う組織 蒸散能ならびにファイバー導光に関する検討を行っ た。

2.ブタ心筋試料への照射実験では，パルス幅の延長に 伴い，熱損倁がやや增強する傾向にみられたが，20 nsと70nsの間で蒸散能には極端な差を認めなかっ t。

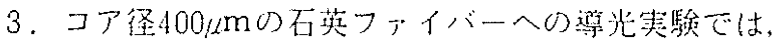
$70 \mathrm{~ns}$ では $16 \mathrm{~mJ} /$ pulse $(128 \mathrm{~mJ} / \mathrm{mni})$ のフイバー 出射端出力が宥定して得ら机た。娄たブタ大動脈

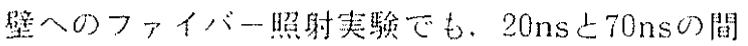
で蒸散能に差在認めなかった。

4.以上上り、今回のパルス幅延曼に伴い，蒸散能の低 下もなく、ファイバー㴪光が簡輋なものとなり，工

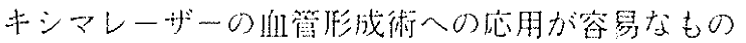
となった。

\section{参考文献}

1) Cirundfest. W, Litvack. F, Coldenberg. T, et al: Pulsed Ultraviolet Lasers and the Potential for Safe Laser Angioplasty, Am. J. Surg, 202(3) : $394-400,1985$

2) Isner. J, Donaldson. R, Deckelbaum. L, et al: The Excimer Laser:Gross, Light Microscopic and Ultrastractural Analysis of Potential Advantages for Use in Laser Therapy of Cardiovascular Disease, J. Am. Coll. Cardiol, Vol (6) : $1102-1109 . \quad 1985$

3 ) Srinivasan. $R$ : Ablation of Polymers and Biological Tissue by Ultraviolet Lasers, Science, $234: 559-565.1986$

4 ) Grundfest. W. Litvack. F, Papaioannou. T, el al: Excimer Laser Angioplasty: From Basic Science to Clinical Trials, Endovascular Surgery, chapter 42, 1989

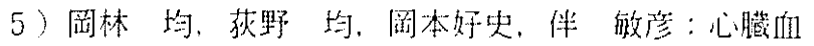
管外科領域に执けるレーザ一の灾用に関子る基筑的 呼究，日本レーザー医学会誌９：25-28，1088

6) 荻野均, 阔林均, 阔本好史, 伴敏彦: 血管内 視鏡下でのExcimer Laser Angioplatyの基硞奏 娩，日本レーザ一医学会誌，10：355-357，1989

7) 荻野均, 阔林均, 阔本好史, 伴敏宸：エキシ

10 日本レーザ一医学会誌 心䑏血管外科学会雑誌，20巻1号，198-199，1990

8 ) Taylor. R.S, Leopold. K.E, Mihailov. S:Damage Mesurements of Fused Silica Fibers Using Long Optical Pulse XeCl Lasers, Opt. Communications, Vol. 63(1): 26-31, 1987

9 ) Singleton. D.L, Paraskevopoulos. G, Taylor. R.S, Higginson. L.A.J:Excimer Laser Angioplasty; Tissue Ablation, Arterial Response,and Fiber Optic Delivery. IEEE, J.Quantum Electron. Vol. QE-23. No. 10. Oct. 1987

$10)$ Taylor. R.S, Singleton. D.L, Paraskepolous. G:Effect of Optical Pulse Duration on the $\mathrm{XeCl}$ Laser Ablation of Polymers and Biological Tissue, Applphys. Lett. 50(25):1779-1781,1987

11) Wollennek. G, Laufer. G, Horvath. R, Stangl. E, Wolner. E:Excimer Laser Angioplasty; Thermal Effects of Deep Ultraviolet laser Radiation on Arterial Walls in Vitro. Lasers in Cardiovas cular Diseases, 1 st International Symposium. Jun. 26-28. 1986

12) Litvack. F, Grundfest. W, Goldenberg. T:Pulsed Laser Angioplasty: Wavelength Power and Energy Dependencies Relevant to Clinical Application. Lasers. Surg. Med.8(1) : 60-64, 1988 